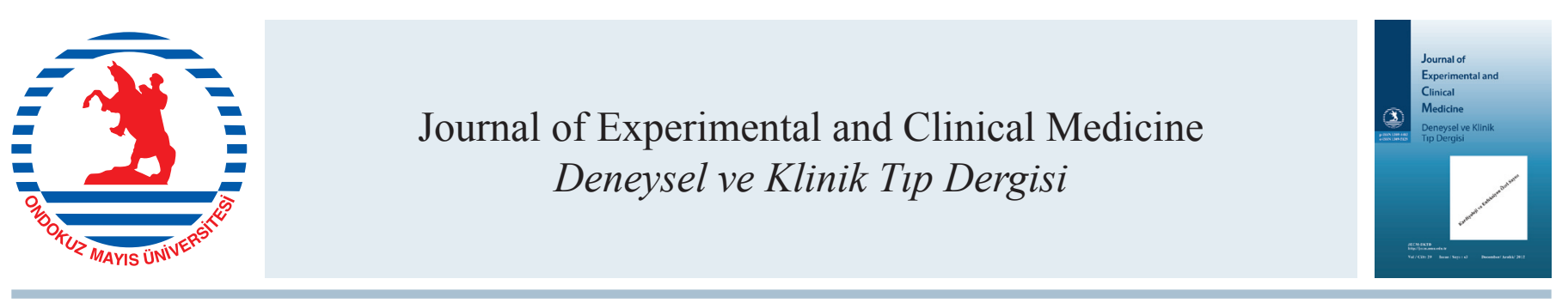

Derleme / Review

doi: $10.5835 /$ jecm.omu.29.s3.014

\title{
Kırım kongo kanamalı ateşi
}

\section{Crimean-congo haemorrhagic fever}

\author{
Pınar Öngürü*, Hürrem Bodur
}

Ankara Numune Ĕgitim ve Araştırma Hastanesi, 2. Enfeksiyon Hastalıklarl ve Kinik Mikrobiyoloji Kliniği, Ankara, Türkiye

\begin{tabular}{|c|c|}
\hline \multicolumn{2}{|c|}{ MAKALE BİLGİLERİ } \\
\hline \multicolumn{2}{|c|}{ Makale geçmişi } \\
\hline Geliş tarihi & $: 25 / 10 / 2011$ \\
\hline Kabul tarihi & $: 22 / 01 / 2012$ \\
\hline
\end{tabular}

\section{* Yazışma Adresi:}

Pınar Öngürü

Ankara Numune Eğitim ve

Araştırma Hastanesi,

2. Enfeksiyon Hastalıkları Kliniğgi,

Ankara, Türkiye

e-posta: pinaronguru@gmail.com

\section{Anahtar Kelimeler:}

Enfeksiyon

Kırım kongo kanamalı ateşi

Kırım kongo kanamalı ateşi virüsü

Nairovirus

Vektör-kaynaklı enfeksiyonlar

Viruslar

\section{Keywords:}

Crimean-congo haemorrhagic fever

Crimean-congo haemorrhagic fever virus

Infection

Nairovirus

Vector-borne infections

Viruses

\section{ÖZET}

Kırım Kongo Kanamalı Ateşi (KKKA) Bunyavirideae ailesi Nairovirus grubundan Kırım Kongo Kanamalı Ateşi Virüsü (KKKAV)'nün etken olduğu ateş ve kanamalarla seyreden bir hastalıktır. KKKAV insanlara sıklıkla Hyalomma cinsi kenelerin tutunması ile bulaşır. Bunun yanında viremik dönemdeki hayvanların enfekte doku ve sekresyonları ile ve akut hastalık dönemindeki insanların kan ve vücut sıvıları ile de bulaşabilir. Hyalomma cinsi keneler hem vektör, hem de rezervuar olarak hastalık epidemiyolojisinde önemli rol oynar. Ülkemizde hastalık ilk kez 2002 yılında başta Tokat ili ve çevresinde görülmüş, tanısı 2003 yılında konmuş, halen İç ve Doğu Anadolu Bölgelerinin kuzeyi ile Karadeniz Bölgesinin güney kesimleri arasında geniş bir coğrafi alanda görülmektedir. Sağlık Bakanlığı verilerine göre kaba ölüm hızı yaklaşık $\% 5$ civarındadır. KKKAV sadece yeni doğan fareler ve insanlarda hastalık yapar. İnkübasyon süresi 2-9 gün arasında olup bu süre virüsün giriş yoluna, alınan virüs miktarına ve konağının immünitesine bağlı olarak değişir. Hastalık ani başlayan baş ağrısı, ateş, miyalji, artralji, halsizlik, bulantı, kusma ile başlar. Kliniğin ağır seyrettiği hastalarda kanamalar tabloya eklenebilir. Hastalar genellikle iki haftada sekelsiz iyileşir, kronikleşme görülmez. Ölüm oranı \%3-30 arasında değişmektedir. Hastalığı geçirenler muhtemelen oluşan nötralizan IgG tipi antikorlara bağlı olarak ömür boyu bağışıklık kazanır. Etkene yönelik kanıtlanmış antiviral tedavisi bulunmayan KKKA'nin esas tedavisi destek tedavisidir. Hiperimmunglobulin uygulamanın özellikle yüksek riskli hastalarda ümit verici olduğunu belirten çalışmalar bulunmaktadır. Hastalıktan korunmada kene ile mücadele ve virüs ile temasın önlenmesi en önemli faktördür. Özellikle endemik bölgede yaşayanların korunma konusunda bilinçlendirilmesi hastalık ile mücadelenin en önemli basamağını oluşturur. J. Exp. Clin. Med., 2012; 29:S175-S181

\section{ABSTRACT}

Crimean-Congo Hemorrhagic Fever (CCHF) is a disease with fever and bleeding that is caused by Crimean-Congo Hemorrhagic Fever Virus (CCHFV) from Nairovirus group in the Bunyavirideae family. CCHF is often transmitted by tick of genus Hyalomma attached to human. In addition, the disease can also be transmittted by tissue and secretions of the infected animals and blood and body fluids of patients in the viremic and acute period of illness. Tick of genus Hyalomma plays an important role in the epidemiology of the disease as a vector and reservoir. The disease was seen for the first time in 2002 in Tokat province of Turkey and around, diagnosed in 2003 and has been still encountered in a wide geographical area including Central and Eastern Anatolia Regions and north and south parts of the Black Sea region. According to Turkish Ministry of Health, death rate is approximately $5 \%$. CCHF affects only humans and newborn mice. Incubation period is 2 to 9 days and this period varies depending on the amount of virus, the mode of acquisition of the virus, and the status of host immunity. Illness begins with sudden onset of headache, fever, myalgia, arthralgia, fatigue, nausea, and vomiting. Bleeding can emerge in the clinic of severely ill patients. Patients usually recover within two weeks without sequelae and chronicity is not observed. The mortality rate varies between 3 and $30 \%$. Recovery from infection maintains lifelong immunity, probably due to the neutralizing IgG antibodies. No proven efficacious antiviral therapy is available for CCHF, the treatment is primarily supportive. Studies are present indicating that the administration of hyperimmunoglobulin might be very promising, especially in patients with high risk for mortality. 
The most important factors for the protection against disease are combating with ticks and avoiding contact with virus. Raising public awareness about prevention, especially in those living in endemic regions creates the most important step in the struggle with the disease.

J. Exp. Clin. Med., 2012; 29: S175-S181

(C) 2012 OMU

\section{Giriş}

Kırım-Kongo Kanamalı Ateşi ilk kez 1944 yılında Kırım'da tanımlanmış, 200'den fazla kişiyi etkilemiştir (Wallace ve ark., 2002). Günümüzde Asya, Afrika ve Güney-Doğu Avrupa'da ülkemizin de içinde bulunduğu 30'dan fazla ülkede halen görülmeye devam etmektedir (Hoogstraal, 1979; Whitehouse, 2004). Sığır, domuz ve tavşan gibi evcil ve yabani hayvanlar Hyalomma cinsi keneler için ara konak özelliğindedir. Keneler ve ara konak özelliğindeki hayvanlarda virüs yaşam döngüsünü sürdürmektedir. Virüsün hayvanlardaki seroprevelansı \%13-36 arasında değişmektedir (Gonzalez ve ark., 1990).

KKKA epidemiyolojisinde Hyalomma cinsi keneler hem vektör, hem de rezervuar olarak önemli rol oynar (Hoogstraal, 1979). KKKAV'nun süt emen fareler dışındaki hayvanlarda klinik olarak sessiz seyretmesi, hastalığın epidemiyolojisinde önemli bir faktördür. Hastalık genel olarak kendi kendini sınırlamakla birlikte kliniğin ağır seyrettiği olgularda doku ve organ kanamaları tabloya eklenebilir. Ölüm oranı \%3-30 arasında değişmektedir (Gonzalez ve ark., 1990; Whitehouse, 2004; Cevik ve ark., 2008). Hastalığın esas tedavisi destek tedavisi olup halen tedavide etkinliği kanıtlanmış antiviral bir ilaç bulunmamaktadır (Hoogstraal, 1979; Gonzalez ve ark., 1990; Wallace ve ark., 2002; Whitehouse, 2004; Aşçığlu ve ark., 2011).

\section{Epidemiyoloji ve etken}

KKKA XII. Yüzyılda Tacikistanlı bir doktor tarafından kanamalarla seyreden bir hastalık olarak fark edilmiş olup ilk kez İkinci Dünya Savaşı sırasında Kırım'da 200'den fazla askeri etkileyen salgın ile tanımlanmıştır. Çıkış yeri nedeni ile hastalığa Kırım Kanamalı Ateşi, saptanan etkene ise Kırım Kanamalı Ateşi Virüsü denmiştir. Bundan yaklaşık 10 sene sonra Kongo'da da benzer özellikle gösteren bir hastadan izole edilen virüsün Kırım'da saptanan virüs ile aynı olduğunun gösterilmesi üzerine etkene KKKAV, hastalığa da KKKA denmiştir (Hoogstraal, 1979). KKKAV kene kaynaklı virüsler içinde en geniş coğrafi dağılıma sahiptir. Hastalık Afrika, Asya, Güney-Doğu Avrupa ve Orta Doğu'da 30'u aşkın ülkede görülmektedir (Hoogstraal, 1979; Whitehouse, 2004). Kene popülasyonunun çoğalmasını hızlandırıcı faktörlerden biri de mevsimsel sıcaklık değişiklikleridir (Gubler ve ark., 2002).

Ülkemizde hastalık daha önce serolojik olarak gösterilmesine rağmen ilk kez 2002 yılında Tokat ve çevresindeki salgınla dikkati çekmiş, tanısı 2003 yılında konmuş olup Karadeniz Bölgesinin güneyi ile İç ve Doğu Anadolu Bölgelerinin kuzey kesimleri arasında geniş bir coğrafi alanda görülmektedir (T.C. Sağlık Bakanlığı, 2010a). Sağlık Bakanlığı son verilerine göre tanısal olarak doğrulanmış vaka sayısı 2002-2007 yılları arasında 1820, ölüm sayısı 92, 2008 yılında vaka sayıs1 1315, ölüm sayısı 63, 2009 yılında ise vaka sayıs1 1318, ölüm sayısı ise 63 olup kaba ölüm hızı \%5 olarak bildirilmiştir (Gözalan ve ark., 2004; Çom, 2008; T.C. Sağlık
Bakanlığı, 2010a). KKKAV, zarflı, tek sarmallı RNA virüsü olup genomu küçük (small-S), orta (medium-M) ve büyük (large-L) segmentlerden oluşur. S segmenti viral nükleokapsid proteinini, M segmenti glikoproteinleri, L segmenti ise RNA-polimerazı kodlar (Andersson ve ark., 2004). S-segment analizlerine göre virüsün 7 türü saptanmıştır (Tonbak ve ark., 2006). Türkiye'de görülen türler Güney-Batı Rusya ve Kosova türleri ile benzerlik göstermektedir.

KKKA'nin insanlara bulaşı kene tutunması, viremik dönemdeki hayvanların enfekte doku veya kanı ile temas ve akut hastalık dönemindeki hastaların kan ve enfekte sekresyonları ile mukozal veya bütünlüğü bozulmuş deri teması ile olmaktadır. Hastalık sıklıkla endemik bölgede yaşayan çiftçilik ve hayvancılıkla uğraşanlarda görülmektedir (Suleiman ve ark., 1980; Whitehouse, 2004; Çom, 2008). T.C. Sağlık Bakanlığı'nın verilerine göre 2002-2007 yılları arasında laboratuar olarak doğrulanmış 1820 olgunun \%68,9'unda kene tutunması öyküsü mevcut olup, hastaların \%61,7'sinde hayvanlarla temas öyküsü vardır (Yılmaz ve ark., 2009). KKKA olan hastaların idrar ve tükrüklerinde KKKAV'nin araştırıldığı bir çalışmada hastaların tükrüğünde ve idrarında virüs RNA'sı gösterilmiştir (Bodur ve ark., 2010a). Anneden bebeğe horizontal geçiş bildirilmiş olup ev içi bulaşın önlenmesi için koruyucu tedbirlerin alınması önemlidir (Saijo ve ark., 2004).

\section{Patogenez}

KKKA'nin patogenezi tam olarak aydınlatılamamıştır. Hemorajik ateş virüslerinin bilinen en önemli özelliği, virüsün konak hücrelerine saldırarak immün cevabın devre dışı bırakılmasıdır (Burt ve ark., 1997). Virüsün replikasyonu ile birlikte vasküler sistem ve lenfoid dokuların regülasyonunda bozulma nedeni ile doku ve organ hasarı oluşur (Feldmann ve ark., 2003). KKKA patogenezinde endotelin rolü büyüktür (Burt ve ark., 1997; Feldmann ve ark., 2003). En önemli hedef vasküler endotel olup hem direkt hem de indirekt olarak hasarlanır. Virüsün etkisi ile salınan proinflamatuar sitokinler damar endoteli, hedef hücreler ve dokularda inflamatuar immün yanita neden olur. İnterlökin (IL)-1, IL-6 ve tümör nekroz faktörü-alfa (TNF-alfa) 'nın KKKA'da yükseldiği, ölen hastalarda TNF-alfa'nın anlamlı düzeyde daha yüksek olduğu saptanmış ve bu sitokinlerin hastalığın patogenezinde önemli rol oynadığı sonucuna varılmıştır (Ergonul ve ark., 2006; Papa ve ark., 2006). Hastalarda eş zamanlı gelişen trombosit agregasyonu ve degranülasyonu hemostaz bozukluğuna neden olur. Ölümcül seyreden hastalarda, hastalığın erken dönemlerinden itibaren koagülasyon sistemi fonksiyonlarında bozukluk olup dissemine intravasküler koagulasyon (DIK)'a yol açabilmektedir (Swanepoel ve ark., 1998). Yapılan bir çalışmada 14 hastanın yedisinde (\%50) reaktif hemafagositoz saptanmış olup KKKA enfeksiyonunda hemafagositozun sitopeni gelişiminde katkısı olduğu düşünülmektedir (Karti ve ark., 2004).

KKKA'da vasküler endotel hasarının araştırıldığı bir 
çalışmada 75 hastanın serumda solubl adezyon molekülleri (sICAM-1, sVCAM-1, sE-selektin, sP-selektin, sL-selektin) ile vasküler endotelyal büyüme faktörü (VEGF) ve makrofaj migrasyon inhibitör faktör (MIF) düzeyleri çalışılmış, kontrol grubu ile karşılaştırıldığında çalışma grubunda sVCAM-1, sL-selektin ve MIF düzeyleri anlamlı derecede yüksek, sICAM-1, sP-selektin, sE-selektin ve VEGF düzeyleri ise anlamlı derecede düşük saptanmıştır. Özellikle sVCAM-1 düzeyleri ölen hastalarda yaşayanlara göre anlam1 derecede yüksek bulunmuştur ve vasküler endotel hasarının hastalık gidişatını etkilediği, sonucuna varılmıştır (Bodur ve ark., 2010b).

Lenfosit alt grupları ile mortalite arasındaki ilişkinin araştırıldığ başka bir çalışmada CD3+ ve CD8+ T sitotoksik lenfositlerin mortal seyreden hastalarda anlamlı olarak daha yüksek olduğu saptanmıştır. Sitotoksik T lenfosit yanıtının viral yük artışı ile paralel olduğu bu durumun yüksek viral yük nedeni ile süpresör immün sistemin aktivasyonuna bağlı olabileceği üzerinde durulmuştur (Swanepoel ve ark., 1998). Başka bir çalışmada da ölen hastalarda DİK skorunun yaşayanlara göre anlamlı derecede daha yüksek olduğu saptanmıştır (Ergonul ve ark., 2006). Patogenezi aydınlatmaya yönelik yapılan başka bir çalışmada; hücresel immün yanıta bağlı interferon-gama (IFN-gama) tarafindan monosit/ makrofajlar ve dentritik hücrelerin uyarıldığı; uyarılan bu hücrelerden salınan neopterin düzeylerinin ölen hastalarda yaşayanlara göre anlamlı derece daha fazla arttığ 1 gösterilmiştir. Bu yüzden özellikle ciddi hastalarda hücre aracılı immün yanıtın hiperaktivasyonu ile inflamatuar yanıtın aşırı derecede oluştuğunu göstermektedir (Onguru ve ark., 2008).

KKKA'da viremi döneminde klinik bulgular görülür. Viral klirens sağlandığında klinik ve laboratuar bulgular da geriler. Viral yükün mortalite ile ilişkisini araştıran çalışmalarda serum viral yükün $\geq 1 \times 10^{9} \mathrm{RNA}$ kopya/mL olmasının mortaliteyi tahmin etmede $\% 80$ prediktif değeri olduğu gösterilmiştir (Çevik ve ark., 2007). Mortal seyreden olgularda IgG gelişmediği, IgG'nin virüs için nötralizan antikorlar olduğunu gösteren çalışmalar da mevcuttur (Duh ve ark., 2007).

\section{Klinik}

KKKAV sadece yeni doğan fareler ve insanlarda hastalık yapar. Çoğu vertebralılarda belirtisiz enfeksiyon oluşturmasına rağmen insanlarda belirtisiz enfeksiyondan şiddetli hemorajik ateşe ve ölüme kadar değişen bir hastalık tablosuna neden olabilir (Mardani, M., 2007; Whitehouse, 2004). Hastalığın inkübasyon süresi 2-9 gün arasında olup bu süre virüsün giriş yoluna, alınan virüs miktarına ve konağının immünitesine bağlı olarak değişir. Güney Afrika'da yapılan bir çalışmada ortalama şikayetlerin başlama zamanı kene ısırmasından sonra 3,2; çiftlik hayvanının kan veya dokuları ile temastan sonra beş, insan kanı ile maruziyetten sonra ise 5,6 gün sonra olarak saptanmıştır (Swanepoel ve ark., 1987).

Hastalık ani başlayan yüksek ateş, baş ağrısı, halsizlik, iştahsızlık, eklem ve kas ağrısı ile başlar. Karın ağrısı, bulantı, kusma, iştahsızlık, ishal ve bazen şuur değişikliği de tabloya eşlik edebilir. Genel olarak klinik tablo hafif olmakla birlikte hastaların az bir kısmında kanama bulguları görülür. Bunlar diş eti kanamaları, gastrointestinal ve genitoüriner sistem, akciğer ve beyin kanamalarıdır (Whitehouse, 2004; Çevik ve ark., 2008). Peteşi ve ekimoz gibi cilt kanamaları da görülebilir. Hepatosplenomegali hastaların yaklaşı \% $\%$ -40'1nda bildirilmiştir. Özellikle akciğer ve beyin kanamalar1 prognozu olumsuz etkiler (Karti ve ark., 2004; Bakır ve ark., 2005). Ağır seyreden olgularda ve hastalığın terminal döneminde santral sinir sistemi disfonksiyonuna bağlı bilinç değişikliği, ajitasyon ve uykuya meyil görülebilir. Akciğerde alveol içine kanama olursa oksijen satürasyonu düşer ve mekanik ventilatör ihtiyacı doğabilir. Nadiren hemodiyaliz gerektirecek derecede böbrek yetmezliği gelişebilir. Ölüm genellikle hastalığın ikinci haftasında görülmekte olup başlıca nedenleri kanamalar, organ yetmezlikleri, şok ve DİK'tir. Altmışdokuz hastanın değerlendirildiği bir çalışmada ölümün hastaneye yattıktan sonra ortalama sekizinci gün (2-19 gün) geliştiği bildirilmiştir (Çevik ve ark., 2008). Hastalar genellikle iki haftada sekelsiz iyileşmekte olup kronikleşme görülmez. Hastalığ1 geçirenler muhtemelen oluşan nötralizan IgG tipi antikorlara bağlı olarak ömür boyu bağışıklık kazanır (Duh ve ark., 2007).

KKKA hastalığının ağırlık kriterlerinin araştırıldığı bir çalışmada aspartat amino transaminaz (AST), kreatin kinaz (CK), laktat dehidrogenaz (LDH) enzimleri ve international normalized ratio (INR) değerleri ölen hastalarda yaşayanlara göre anlamlı derecede daha yüksek bulunmuş, şuur değişikliği ve splenomegali mortalite ile ilişkili bağımsız risk faktörleri olarak tanımlanmıştır (Bakır ve ark., 2005). Mortalite ile ilişkili risk faktörlerinin araştırıldığ ekimoz, melena, hematemez, diş eti kanaması ve şuur değişikliği ölen hastalarda anlamlı derecede daha yüksek oranda saptanmıştır. Yine ölen hastalarda trombosit sayısının daha düşük; pıhtılaşma zamanı (PT) ile aktive parsiyel tromboplastin zamanının (aPTT) daha uzun; INR, ALT, AST, LDH ve CK değerlerinin daha yüksek olduğu tespit edilmiştir. Melena ve şuur değişikliğinin bulunması; trombosit sayısının $\leq 20,000 / \mathrm{mm}^{3}$ ile, aPTT'nin $\geq 60$ sn olmas1; mortalite ile ilişkili bağımsız risk faktörleri olarak belirlenmiştir (Çevik ve ark., 2008).

\section{Laboratuar bulgular}

KKKA hastalığının seyrinde görülebilecek laboratuar değişiklikleri: Anemi, lökopeni, trombositopeni, AST ve ALT düzeylerinde artış, PT, aPTT ve INR sürelerinde uzama, fibrin yıkım ürünlerinde artma ve fibrinojende azalmadır. Karaciğer tutulumuna bağlı olarak hemostazda bozukluk, AST, ALT ve LDH enzimlerinde yükseklik, albümin ve total proteinde düşüklük görülür. Kas tutulumuna bağlı CK ve AST yükselir. Oral alım bozukluğu ve renal tutuluma bağlı proteinüri, hematüri, oligüri ve azotemi gelişebilir. Akciğer tutulumu ve alveol içine kanamaya bağlı kan gazında kötüleşme tabloya eşlik edebilir (Bakır ve ark., 2005; Çevik ve ark., 2008).

\section{Tanı}

Endemik bölge ile epidemiyolojik ilişkisi olan klinik olarak KKKA düşünülen hastalarda öncelikli olarak tam kan sayımı yapılmalıdır. Trombosit sayıs $1<150,000 / \mathrm{mm}^{3}$ ve/veya lökosit sayısı $<4.000 / \mathrm{mm}^{3}$ olanlarda KKKA doğrulaması yapılmalıdır (T.C. Sağlık Bakanlığı, 2010b). KKKA tanısında kullanılan başlıca yöntemler virüs kültürü, seroloji ve moleküler yöntemlerdir. Serumda spesifik IgM ve IgG tipi antikorlar, EIA (enzyme-linked immunoassay) veya ELISA (enzyme-linked immunosorbent assay) yöntemleri ile hastal1ğın başlangıcından ortalama 6 gün sonra saptanabilmektedir. Tanı tek başına IgM pozitifliği ile veya akut ve konvelesan 
dönemde alınan serum örneklerinde IgG titresinde 4 katlık titre artışının saptanması ile konmaktadır. IgM tipi antikorlar serumda 4 aya kadar pozitif kalabilmekte, IgG tipi antikorlar ise zaman içinde azalmaktadır (WHO, 2001).

Özellikle mortal seyreden hastalarda hastalığın ilk günlerinde antikorlarının ölçülebilir düzeye ulaşamaması nedeni ile tanı için kan veya dokudan virüs saptanabilir. Hastalığın ilk birkaç gününde kan veya dokudan virüs izole edilebilse de biyogüvenlik seviyesi 4 düzeyinde olan laboratuar gerekliliği, bu yöntemin uygulanabilirliğini kısıtlamaktadır (WHO, 2001; Yapar ve ark., 2005). Real-time reverse transcriptasePCR (RT-PCR) yöntemi gibi virüsün nükleik asidini saptamaya yönelik yöntemler tanıda daha sık kullanılmakta olup kandaki virüs yükünü de gösterebilmesi nedeniyle daha kullanışlıdır (Saijo ve ark., 2002; Yapar ve ark., 2005).

\section{Tedavi}

Klinik ve laboratuar olarak KKKA düşünülen hastalar hastalığın başlangıç döneminde genellikle hastaneye yatırılarak izlenmelidir. Genel durumu iyi ve laboratuar bulguları hafif derecede bozulmuş olan, çevresine bulaştırma riski olmayan, takip konusunda uyumlu hastalar ayaktan izlenebilir. Hastalığın esas tedavisi destek tedavisidir. Sivı ve elektrolit desteğinin sağlanması, gerekli olduğu durumlarda kan ve kan ürünleri (trombosit süspansiyonu, taze donmuş plazma, eritrosit süspansiyonu) replasmanının yapılması gereklidir. Tedavide antibiyotiklerin yeri olmamakla birlikte, bakteriyel enfeksiyonların araya girmesi durumunda uygun antibiyotik(ler) verilmelidir. Solunum yetmezliği durumunda mekanik ventilasyon desteği, böbrek yetmezliği geliştiğinde de hemodiyaliz uygulanmalıdır. Ülser profilaksisi ve oral beslenemeyen hastalarda parenteral beslenme desteği sağlanmalidır.

Etkene yönelik tedavide ribavirin denenmiştir. Ribavirin bir guanozin analoğu olup hücre içi fosforilasyondan sonra ribavirin trifosfata dönüşerek viral transkripsiyonunun erken fazını inhibe eder (Wray ve ark., 1985). Rift vadisi ateşi virüsü, Hantaan virüs ve Lassa virüs enfeksiyonlarının tedavisinde ribavirin etkili bulunmuştur (McCormick ve ark., 1986; Huggins, 1989; Garcia ve ark., 2001). İn vitro vero hücre modellerinde ve in vivo hayvan modellerinde ribavirinin KKKAV'nin replikasyonunu inhibe ettiği gösterilmiştir (Watts ve ark., 1989; Tignor ve Hanham, 1993).

KKKA'lı hastalarda ribavirin tedavisinin etkili olduğunu bildiren vaka serileri olması nedeni ile Dünya Sağlık Örgütü KKKA'da ribavirin kullanılmasını önermektedir (FisherHoch ve ark., 1995; Borio ve ark., 2002; Ergonul ve ark., 2004; WHO, 2009). İran'dan bildirilen iki gözlemsel çalışmada ribavirinin KKKA tedavisinde etkili olduğu bildirilmiştir (Mardani ve ark., 2003; Alavi-Naini ve ark., 2006). Ülkemizden yapılan oral ribavirin alan 22 hasta ile almayan 38 hastanın karşılaştırıldığı başka bir çalışmada ise ribavirinin mortalite üzerine etkili olmadığı gösterilmiştir (Ozkurt ve ark., 2006). Elaldı ve ark.'nın yaptığı, KKKA'de ribavirin alan 126 hasta ile almayan 92 hastanın karşılaştırıldığı çok merkezli yarı deneysel çalışmada ise ribavirinin mortalite üzerine etkisinin olmadığı, paradoksal olarak ilk sekiz günde ribavirin alan hastalarda mortalitenin daha yüksek olduğu saptanmıştır. Bu durumun nedeni olarak karaciğer ve böbreğe toksik olan ribavirinin, KKKA enfeksiyonunun renal ve hepatotoksik etkilerini potansiyalize edebileceği üzerinde du- rulmuştur (Elaldı ve ark., 2009).

KKKA'da ribavirinin etkinliği ile ilgili yapılmış tek randomize kontrollü çalışmada ribavirin alan 64 hasta ile kontrol grubundaki 72 hasta karşılaştırılmış, çalışma grubunda lökosit sayısının normale dönme süresinin, kontrol grubuna göre daha uzun olması $(\mathrm{p}=0,03)$ dışında her iki grup arasında klinik ve laboratuar parametrelerde istatistiksel olarak anlamlı fark saptanmamıştır. Bu nedenle ribavirin tedavisinin KKKA enfeksiyonunun prognozuna anlamlı katkısının olmadığı belirtilmiştir (Köksal ve ark., 2009). Ribavirinin intravenöz (IV) formunun mortaliteye etkisinin araştırıldığı bir çalışmada IV ribavirin alan ve almayan hastalar arasında mortalite açısından istatistiksel olarak anlamlı fark saptanmamıştır (Çevik ve ark., 2008).

Aşçıŏlu ve ark.'nın yaptığı KKKA'da ribavirin etkinliğinin değerlendirildiği metaanalizde, 2010 yılına kadar KKKA konusunda yapılan çalışmalar incelenmiş, sonuç olarak KKKA'da ribavirin tedavisinin mortalite üzerine bir etkisinin olmadığı saptanmıştır (Aşçıŏlu ve ark., 2011). KKKA tedavisinde hiperimmün serum etkinliği hakkında ilk tecrübe Eski Sovyetler Birliğindeki çiftçilerde görülen salgında, konvelesan fazdaki hastaların serumlarının akut hastalık döneminde kullanılabileceği belirtilmiştir (CDC, 1988). Bulgaristan'da 1970'li yıllardan itibaren aşı sonrası sağlıklı donörlerden elde edilen immünglobülinlerin tedavide kullanıldığ 1 ve başarılı sonuçlar alındığı ve intravenöz immunglobulinin ciddi hastalarda etkili olabileceği belirtilmiştir (Vassilenko ve ark., 1990).

KKKA tedavisinde hiperimmunglobulin uygulamasının araştırıldığı bir başka çalışmada; KKKA enfeksiyonu geçiren sağlıklı donörlerden elde edilen serumlardan oluşturulan plazma havuzundan elde edilen hiperimmünglobülin mortalite açısından yüksek riskli hastalarda kullanılmış, yüksek riskli grupta yer alan 15 hastanın sağ kalım oranları \%86,6 (13/15) bulunmuştur. Sonuç olarak mortalite açısından özellikle yüksek riskli hastalarda KKKAV hiperimmünglobulin uygulamanın tedavide ümit verici olduğu belirtilmiştir $(\mathrm{Ku}-$ bar ve ark., 2011). KKKA tedavisinde denenen diğer bir alternatif interferondur. Nozokomiyal bir salgında interferon kullanılmış, hastalığın belirtilerini taklit eden yan etkileri nedeni ile interferon tedavisi kesilmek zorunda kalınmıştır (Van Eeden ve ark., 1985).

\section{Korunma ve kontrol}

Hastalıktan korunmada en önemli faktör virüs ile teması önleyerek hastalığın bulaştırıcılığını engellemektir. Endemik bölgede yaşayan kişiler hastalık konusunda bilgilendirilmeli, kene tutunmasına karşı enfekte hayvanın kan veya diğer materyalleri ile temas etmemek için alınması gereken önlemler konusunda eğitilmelidir. Mümkün olduğunca kenenin bulunduğu alanlardan kaçınılması, bu mümkün değilse permetrin emdirilmiş giysilerin giyilmesi, pantolonun paçalarını çorabın içine sokulması, kenelerin daha iyi görünmesi için açık renkli giysilerin giyilmesi, cilde kene kovucu repellent sürülmesi ve vücutta günlük kene kontrolü yapılması önerilmektedir (Connor, 1990).

Akut hastalık döneminde hastanın kan ve vücut sekresyonları bulaştırıcı olduğundan hastaya bakım veren ve müdahale eden sağlı personeli gerekli personel koruyucu önlemleri almalıdır. Hastalığın sağlık personeline veya diğer hastalara bulaşmasını engellemek için evrensel korunma ön- 
lemleri alınmalıdır. Bu yüzden KKKA ön tanısı ile yatan hastalar mümkün ise tek kişilik odalara alınmalı, değil ise tanısı aynı olan hastalar bir arada yatacak şekilde kohortlanmalıdır. Hastalarla ilgilenen personel sayısı minimalde tutulmalı, müdahale sırasında gerekli bariyer önlemleri alınmalıdır. Hastaya müdahale sırasında tek kullanımlık eldiven giyilmeli, bir metreden daha yakın mesafeden müdahale edilecekse cerrahi maske ve gözlük takılmalıdır. Burun, diş eti ve akciğer içi kanaması olan hastalara müdahale etmeden önce öksürük ve aksırıkla virüsün aerosolize olma ihtimaline karş1, koruyuculuğu yüksek olan FFP veya N95 gibi filtreli maskeler takılmalıdır. Hastalara ait kan ve vücut sıvıları ile temastan kaçınılmalı, böyle bir durum söz konusu olduğunda cilt su ve sabunla, mukozal bölge ise bol su ile yıkanmalı, temaslı kişi en az 14 gün süreyle ateş ve diğer belirtiler yönünden takip edilmelidir (CDC, 1995).

Temas sonrası ribavirin proflaksisi ile ilgili değişik tecrübeler bulunmaktadır. Pakistan'da KKKA ile enfekte hastanın iğnesinin battığ $\breve{b i r}$ hemşire ile dört hasta bakıcıya proflaktik ribavirin başlanmasına rağmen tüm sağlık çalışanlarında hastalık gelişmiş ve tümü hayatını kaybetmiştir (Sheikh ve ark., 2005). Temas sonrası ribavirin proflaksisi vermek için daha fazla çalışmaya ihtiyaç vardır. Bulgaristan'da süt emen fare beyninden elde edilen inaktive aşı askeri personele ve riskli sağlık çalışanlarına bir ay ara ile iki doz şeklinde uygulanmaktadır (1. ve 5. y1llarda rapel). Bu yöntem ile vaka sayısında azalma olduğu ileri sürülse de halen KKKA enfeksiyonundan korunmada, Dünya Sağl1k Örgütü’nün kabul ettiği standartlarda üretilmiş ticari bir aşı bulunmamaktadır (CDC, 1995; Christova ve ark, 2008).

Sonuç olarak KKKA ülkemizde 2002 yılından beri önemli bir halk sağlığı sorunu olmaya devam etmektedir. Hastalık bulaşında en önemli rolü keneler oynadığından kene ile mücadele KKKA'ni önlemenin en önemli basamağını oluşturmaktadır. Özellikle endemik bölgede yaşayanları hastalık ve korunma yolları konusunda eğitmek hastalığın kontrol altına alınmasında önemlidir. KKKA hastalığının tedavisinin esasını destek tedavisi oluşturmaktadır. Etkene yönelik etkinliği kanıtlanmış antiviral bir ajan bulunmamaktadır. Ribavirin etkinliği ile ilgili mevcut veriler mortalite üzerine olumlu bir etkisinin olmadığı yönündedir. Kanıt düzeyi tartışmasız olan randomize kontrollü çalışma ile ribavirin etkinliği araştırılmalıdır. Tedavide hiperimmüm serum uygulaması ümit verici bir gelişmedir. Gelecekte aşı ve antiserum geliştirerek riskli teması olanların immünizasyonunu sağlamak hedef alınmalıdir.

\section{KAYNAKLAR}

Alavi-Naini, R., Moghtaderi, A., Koohpayeh, H.R., Sharifi-Mood, B., Naderi, M., Metanat, M., Izadi, M., 2006. Crimean-Congo hemorrhagic fever in Southeast of Iran. J. Infect. 52, 378-382.

Andersson, I., Simon, M., Lundkvist, A., Nilsson, M., Holmström, A., Elgh, F., Mirazimi, A., 2004. Role of actin filaments in targeting of Crimean Congo hemorrhagic fever virus nucleocapsid protein to perinuclear regions of mammalian cells. J. Med. Virol. 72, 83-93.

Ascioglu, S., Leblebicioglu, H., Vahaboglu, H., Chan, K.A., 2011. Ribavirin for patients with Crimean-Congo haemorrhagic fever: A systematic review and meta-analysis. J. Antimicrob. Chemoth. 66, 1215-1222.

Bakir, M., Ugurlu, M., Dokuzoguz, B., Bodur, H., Tasyaran, M.A., Vahaboglu, H., Turkish CCHF Study Group, 2005. Crimean-Congo haemorrhagic fever outbreak in Middle Anatolia: A multicentre study of clinical features and outcome measures. J. Med. Microbiol. 54, $385-389$.

Bodur, H., Akinci, E., Ongürü, P., Carhan, A., Uyar, Y., Tanrici, A., Cataloluk, O., Kubar, A., 2010a. Detection of Crimean-Congo hemorrhagic fever virus genome in saliva and urine. Int. J. Infect. Dis. 14, 247-249.

Bodur, H., Akinci, E., Onguru, P., Uyar, Y., Basüturk, B., Gozzel, M.G., Kayaaslan, B.U., 2010b. Evidence of vascular endothelial damage in Crimean-Congo hemorrhagic fever. Int. J. Infect. Dis. 14, 704-707.

Borio, L., Inglesby, T., Peters, C.J., Schmaljohn, A.L., Hughes, J.M., Jahrling, P.B., Ksiazek, T., Johnson, K.M., Meyerhoff, A., O’Toole, T., Ascher, M.S., Bartlett, J., Breman, J.G., Eitzen, E.M. Jr, Hamburg, M., Hauer, J., Henderson, D.A., Johnson, R.T., Kwik, G., Layton, M., Lillibridge, S., Nabel, G.J., Osterholm, M.T., Perl, T.M., Russell, P., Tonat, K., Working Group on Civilian Biodefense, 2002. Hemorrhagic fever viruses as biological weapons: Medical and public health management. J.A.M.A. 287, 2391-2405.

Burt, F.J., Swanepoel, R., Shieh, W.J., Smith, J.F., Leman, P.A., Greer, P.W., Coffield, L.M., Rollin, P.E., Ksiazek, T.G., Peters, C.J., Zaki, S.R., 1997. Immunohistochemical and in situ localization of Crimean-Congo hemorrhagic fever (CCHF) virus in human tissues and implications for CCHF pathogenesis. Arch. Pathol. Lab. Med.121, 839-846.

Centers for Disease Control (CDC), 1998. Management of patients with suspected viral hemorrhagic fever. M.M.W.R 3, 1-16.

Centers for Disease Control and Prevention (CDC), 1995. Update: Management of patients with suspected viral hemorrhagic fever-United States. M.M.W.R. 44, 475-479.

Christova, I., Tasseva, E., Gladnishka T, 2008. Investigations on Tick-born infections in Bulgaria. Dr. Mustafa Aydın Çevik Anısına, II. Türkiye Zoonotik Hastalıklar Sempozyumu Bildiri Kitabı. Ankara: Medisan Yayıncılık, 167-170.

Connor, J., 1990. Ribavirin pharmacokinetics. Pediatr. Infect. Dis. J. 9, 91-92.

Çevik, M.A., Erbay, A., Bodur, H., Eren, S.S., Akinci, E., Sener, K., Ongürü, P., Kubar, A., 2007. Viral load as a predictor of outcome in CrimeanCongo hemorrhagic fever. Clin. Infect. Dis. 1, 45.

Çevik, M.A., Elaldi, N., Akinci, E., Onguru, P., Erbay, A., Buzgan, T., Uzun, R., Kubar, A., Bodur , H., 2008. A preliminary study to evaluate the effect of intravenous ribavirin treatment on survival rates in Crimean-Congo hemorrhagic fever. J. Infect. 57, 350-351.

Çevik, M.A., Erbay, A., Bodur, H., Gülderen, E., Baştuğ, A., Kubar, A., Akinci, E., 2008. Clinical and laboratory features of Crimean-Congo hemorrhagic fever: Predictors of fatality. Int. J. Infect. Dis. 12, 374-379.

Çom, S., 2008. Kırım kongo kanamalı ateşi: Ülkemizdeki son durum. Dr. Mustafa Aydın Çevik Anısına, II. Türkiye Zoonotik Hastalıklar Sempozyumu Bildiri Kitabı. Ankara, Medisan Yayınc1lık, 45-47.

Duh, D., Saksida, A., Petrovec, M., Ahmeti, S., Dedushaj, I., Panning, M., Drosten, C., Avsic-Zupanc, T., 2007. Viral load as predictor of Crimean-Congo hemorrhagic fever outcome. Emerg. Infect. Dis. 13, 1769-1772.

Elaldi, N., Bodur, H., Ascioglu, S., Celikbas, A., Ozkurt, Z., Vahaboglu, H., Leblebicioglu, H., Yilmaz, N., Engin, A., Sencan, M., Aydin, K., Dokmetas, I., Cevik, M.A., Dokuzoguz, B., Tasyaran, M.A., Ozturk, R, Bakir, M., Uzun, R., 2009. Efficacy of oral ribavirin treatment in Crimean-Congo haemorrhagic fever: A quasi-experimental study from Turkey. J. Infect. 58, 238-244.

Ergonul, O., Celikbas, A., Dokuzoguz, B., Eren, S., Baykam, N., Esener, H., 2004. Characteristics of patients with Crimean-Congo hemorrhagic fever in a recent outbreak in Turkey and impact of oral ribavirin therapy. Clin. Infect. Dis. 39, $284-287$. 
Ergonul, O., Tuncbilek, S., Baykam, N., Celikbas, A., Dokuzoguz, B., 2006. Evaluation of serum levels of interleukin (IL)-6, IL-10, and tumor necrosis factor-alpha in patients with Crimean-Congo hemorrhagic fever. J. Infect. Dis. 193, 941-944.

Feldmann, H., Jones, S., Klenk, H.D., Schnittler, H.J., 2003. Ebola virus: From discovery to vaccine. Nat. Rev. Immunol. 3, 677-685.

Fisher-Hoch, S.P., Khan, J.A., Rehman, S., Mirza, S., Khurshid, M., McCormick, J.B., 1995. Crimean Congo-haemorrhagic fever treated with oral ribavirin. Lancet. 346, 472-475.

Garcia, S., Crance, J.M., Billecocq, A., Peinnequin, A., Jouan, A., Bouloy, M., Garin, D., 2001. Quantitative real-time PCR detection of Rift Valley fever virus and its application to evaluation of antiviral compounds. J. Clin. Microbiol. 39, 4456-4461.

Gonzalez, J.P., LeGuenno, B., Guillaud, M., Wilson, M.L., 1990. A fatal case of Crimean-Congo haemorrhagic fever in Mauritania: Virological and serological evidence suggesting epidemic transmission. T. Roy. Soc. Trop. Med. H. 84, 573-576.

Gözalan, A., Akin, L., Rolain, J.M., Tapar, F.S., Oncül, O., Yoshikura, H., Zeller, H., Raoult, D., Esen, B., 2004. Epidemiological evaluation of a possible outbreak in and nearby Tokat province. Mikrobiyol. Bul. 38, 33-44.

Gubler, D.J., Reiter, P., Ebi, K.L., Yap, W., Nasci, R., Patz, J.A., 2001. Climate variability and change in the United States: Potential impacts on vector- and rodent-borne diseases. Environ. Health Perspect. 109, 223-233.

Hoogstraal, H., 1979. The epidemiology of tick-borne Crimean-Congo hemorrhagic fever in Asia, Europe, and Africa. J. Med. Entomol. 15, 307-417.

Huggins, J.W., 1989. Prospects for treatment of viral hemorrhagic fevers with ribavirin, a broad-spectrum antiviral drug. Rev. Infect. Dis. 11, 750-761.

Karti, S.S., Odabasi, Z., Korten, V., Yilmaz, M., Sonmez, M., Caylan, R., Akdogan, E., Eren, N., Koksal, I., Ovali, E., Erickson, B.R., Vincent, M.J., Nichol, S.T., Comer, J.A., Rollin, P.E., Ksiazek, T.G., 2004. Crimean-Congo hemorrhagic fever in Turkey. Emerg. Infect. Dis. 10, 1379-1384.

Koksal, I., Yilmaz, G., Aksoy, F., Aydin, H., Yavuz, I., Iskender, S., Akcay, K., Erensoy, S., Caylan, R., Aydin, K., 2010. The efficacy of ribavirin in the treatment of Crimean-Congo hemorrhagic fever in Eastern Black Sea region in Turkey. J. Clin. Virol. 47, 65-68.

Kubar, A., Haciomeroglu, M., Ozkul, A., Bagriacik, U., Akinci, E., Sener, K., Bodur, H., 2011. Prompt administration of Crimean-Congo Hemorrhagic Fever (CCHF) Virus Hyperimmunoglobulin in patients diagnosed with CCHF and viral load monitorization by reverse TranscriptasePCR. Jpn J. Infect. Dis. 64, 439-443.

Mardani, M., Jahromi, M.K., Naieni, K.H., Zeinali, M., 2003. The efficacy of oral ribavirin in the treatment of crimean-congo hemorrhagic fever in Iran. Clin. Infect. Dis. 36, 1613-1618.

Mardani, M., Keshtkar-Jahromi, M., 2007. Crimean-Congo hemorrhagic fever. Arch. Iran. Med. 10, 204-214.

McCormick, J.B., King, I.J., Webb, P.A., Scribner, C.L., Craven, R.B., Johnson, K.M., Elliott, L.H., Belmont-Williams, R., 1986. Lassa fever. Effective therapy with ribavirin. New Engl. J. Med. 314, 20-26.

Onguru, P., Akgul, E.O., Akinci, E., Yaman, H., Kurt, Y.G., Erbay, A., Bayazit, F.N., Bodur, H., Erbil, K., Acikel, C.H., Cevik, M.A., 2008. High serum levels of neopterin in patients with Crimean-Congo hemorrhagic fever and its relation with mortality. J. Infect. 56, 366-370.

Ozkurt, Z., Kiki, I., Erol, S., Erdem, F., Yilmaz, N., Parlak, M., Gundogdu, M., Tasyaran, M.A., 2006. Crimean-Congo hemorrhagic fever in Eastern Turkey: Clinical features, risk factors and efficacy of ribavirin therapy. J. Infect. 52, 207-215.

Papa, A., Bino, S., Velo, E., Harxhi, A., Kota, M., Antoniadis, A., 2006. Cytokine levels in Crimean-Congo hemorrhagic fever. J. Clin. Virol. $36,272-276$.

Saijo, M., Qing, T., Niikura, M., Maeda, A., Ikegami, T., Sakai, K., Prehaud, C., Kurane, I., Morikawa, S., 2002. Immunofluorescence technique using HeLa cells expressing recombinant nucleoprotein for detection of immunoglobulin $\mathrm{G}$ antibodies to Crimean-Congo hemorrhagic fever virus. J. Clin. Microbiol. 40, 372-375.

Saijo, M., Tang, Q., Shimayi, B., Han, L., Zhang, Y., Asiguma, M., Tianshu, D., Maeda, A., Kurane, I., Morikawa, S., 2004. Possible horizontal transmission of crimean-congo hemorrhagic Fever virus from a mother to her child. Jpn J. Infect. Dis. 57, 55-57.

Schnittler, H.J., Feldmann, H., 2003. Viral hemorrhagic fever a vascular disease? Thromb Haemost. 89, 967-972.

Schwarz, T.F., Nsanze, H., Ameen, A.M., 1997. Clinical features of Crimean-Congo haemorrhagic fever in the United Arab Emirates. Infection. 25, 364-367.

Sheikh, A.S., Sheikh, A.A., Sheikh, N.S., Rafi-U-Shan, Asif, M., Afridi, F., Malik, M.T., 2005. Bi-annual surge of Crimean-Congo haemorrhagic fever (CCHF): A five-year experience. Int. J. Infect. Dis. 9, 37-42.

Suleiman, M.N., Muscat-Baron, J.M., Harries, J.R., Satti, A.G., Platt, G.S., Bowen, E.T., Simpson, D.I., 1980. Congo/Crimean haemorrhagic fever in Dubai. An outbreak at the Rashid Hospital. Lancet. 2, 939-941.

Swanepoel, R., Leman, P.A., Burt, F.J., Jardine, J., Verwoerd, D.J., Capua, I., Brockner, G.K., Burger, W.P., 1998. Experimental infection of ostriches with Crimean-Congo haemorrhagic fever virus. Epidemiol. Infect. 121, 427-432.

Swanepoel, R., Shepherd, A.J., Leman, P.A., Shepherd, S.P., McGillivray, G.M., Erasmus, M.J., Searle, L.A., Gill, D.E., 1987. Epidemiologic and clinical features of Crimean-Congo hemorrhagic fever in southern Africa. Am. J. Trop. Med. Hyg. 36, 120-132.

T.C. Sağlık Bakanlığı, Kırım Kongo Kanamalı Ateşi web sitesi, 26/02/2010a Tarihli Açılklama:http://www.kirimkongo.gov.tr/index. php?option=com_content\&view=article \&id=100:26022010-tarihli-acklama\&catid=44:basn-acklamalar

T.C. Sağlık Bakanlığı, Kırım Kongo Kanamalı Ateşi web sitesi, 15/04/2010b Tarihli Genelge:http://www.kirimkongo.gov.tr/images/stories/mevzuat/Genelge_15.04.20101.pdf

Tignor, G.H., Hanham, C.A., 1993. Ribavirin efficacy in an in vivo model of Crimean-Congo hemorrhagic fever virus (CCHF) infection. Antiviral Res. 22, 309-325.

Tonbak, S., Aktas, M., Altay, K., Azkur, A.K., Kalkan, A., Bolat, Y., Dumanli, N., Ozdarendeli, A., 2006. Crimean-Congo hemorrhagic fever virus: Genetic analysis and tick survey in Turkey. J. Clin. Microbiol. 44, 4120-4124.

van Eeden, P.J., van Eeden, S.F., Joubert, J.R., King, J.B., van de Wal, B.W., Michell, W.L., 1985. A nosocomial outbreak of Crimean-Congo haemorrhagic fever at Tygerberg Hospital. Part II. Management of patients. Samj. S. Afr. Med. J. 68, 718-721.

Vassilenko, S.M., Vassilev, T.L., Bozadjiev, L.G., Bineva, I.L., Kazarov, G.Z., 1990. Specific intravenous immunoglobulin for Crimean-Congo haemorrhagic fever. Lancet. 335, 791-792.

Wallace, M.R., Hale, B.R., Utz ,G.C., Olson, P.E., Earhart, K.C., Thornton, S.A., Hyams, K.C., 2002. Endemic infectious diseases of Afghanistan. Clin. Infect. Dis. 34, 171-207.

Watts, D.M., Ussery, M.A., Nash, D., Peters, C.J., 1989. Inhibition of Crimean-Congo hemorrhagic fever viral infectivity yields in vitro by ribavirin. Am. J. Trop. Med. Hyg. 41, 581-585. 
Whitehouse, C.A., 2004. Crimean-Congo hemorrhagic fever. Antiviral Res. 64, 145-160.

WHO, 2009. World Health Organization. http://www.who.int/mediacentre/factsheeds/fs208/en/print.htlm. Accessed date: 2009 February 07.

WHO, 2001. Crimean-Congo hemorrhagic fever. November, 208.

Wray, S.K., Gilbert, B.E., Knight, V., 1985. Effect of ribavirin triphosphate on primer generation and elongation during influenza virus transcription in vitro. Antiviral Res. 5, 39-48.

Yapar, M., Aydogan, H., Pahsa, A., Besirbellioglu, B.A., Bodur, H., Basustaoglu, A.C., Guney, C., Avci, I.Y., Sener, K., Setteh, M.H., Kubar, A., 2005. Rapid and quantitative detection of Crimean-Congo hemorrhagic fever virus by one-step real-time reverse transcriptase-PCR. Jpn J. Infect. Dis. 58, 358-362.

Yilmaz, G.R., Buzgan, T., Irmak, H., Safran, A., Uzun, R., Cevik, M.A., Torunoglu, M.A., 2009. The epidemiology of Crimean-Congo hemorrhagic fever in Turkey, 2002-2007. Int. J. Infect. Dis. 13, 380-386. 